\title{
BIOFORTIFICATION: A SUSTAINABLE AGRONOMIC STRATEGY TO INCREASE SELENIUM CONTENT AND ANTIOXIDANT ACTIVITY IN GARLIC
}

\author{
SHAFIQ, M. $.^{1,2^{*}}-$ QADIR, A. ${ }^{1}-$ AHMAD, S. R. ${ }^{1}$ \\ ${ }^{1}$ College of Earth and Environmental Sciences (CEES), Faculty of Science, University of the \\ Punjab, Lahore, Pakistan \\ ${ }^{2}$ Biotechnology and Food Research Centre, PCSIR Laboratories Complex \\ Lahore-54600, Pakistan \\ *Corresponding author \\ e-mail: organicfoodlab@gmail.com \\ (Received 29 $9^{\text {th }}$ Aug 2018; accepted $5^{\text {th }}$ Nov 2018)
}

\begin{abstract}
The process of breeding to enhance nutrients, such as vitamins and minerals, in food crops through biofortification is a sustainable, eco-friendly and powerful strategy to overcome micronutrient deficiency. Therefore, the aim of the present investigation was to increase selenium content in edible parts of garlic (Allium sativum L.) supplied with either $20 \mathrm{~g} / \mathrm{ha}$ or $50 \mathrm{~g} / \mathrm{ha}$ aqueous solution of anhydrous sodium selenate. This was done either through foliar spray or soil flood application under open-field conditions. Results indicated that the $50 \mathrm{~g} / \mathrm{ha}$ concentration of sodium selenate application in the form of foliar spray significantly enhanced the selenium content in garlic bulb $(3.23 \pm 0.16 \mathrm{mgSe} / \mathrm{Kg})$ and vegetative part $(15.46 \pm 0.71 \mathrm{mgSe} / \mathrm{Kg})$ that is, a 12.52 and 7.8 fold increase was observed respectively, as compared to control. A significant increase in total phenolic content $(4.72 \pm 1.79 \mathrm{GAE} / 100 \mathrm{~g})$, total flavonoid content $(18.50 \pm 1.82 \mathrm{mgQE} / 100 \mathrm{~g})$ and total antioxidant capacity $\left(\mathrm{IC}_{50} \mathrm{of} 0.81 \mathrm{mg} / \mathrm{ml}\right.$ determined through DPPH radical scavenging assay) was also observed in the bulbous part of garlic. The results suggested that the consumption of $16 \mathrm{~g}$ of dried garlic bulb, biofortified with $50 \mathrm{~g} \mathrm{Se} / \mathrm{ha}$, could cover the daily recommended dose of selenium for human beings. Selenium biofortified garlic crop can hold a market value as selenium functional food and can be used as an alternative to synthetic selenium supplements to overcome selenium deficiency.
\end{abstract}

Keywords: Allium sativum; antioxidant activity; flavonoid content; malnutrition; polyphenols

\section{Introduction}

Many people, particularly those living in developing countries are facing a silent crisis of malnutrition or hidden hunger (Swaminathan, 2012, Muthayya et al., 2013). About half of the world's inhabitants suffer in macronutrients and micronutrients deficiency which is responsible for 20 million adult deaths and more than five million childhood mortalities annually (Zhao and McGrath, 2009, Bouis and Welch, 2010) . In developing countries many food systems cannot provide adequate micronutrients to meet the demands of their citizens, especially families having fewer income resources (Bouis and Welch, 2010, El-Ramady et al., 2015). It is reported that among the six billion people in the world more than $15 \%$ are suffering from selenium deficiency (Fordyce, 2013). A range of chronic diseases have been associated with selenium deficiency including Keshan (an endemic congestive cardiomyopathy in China, with high rate of fatality) (Yang et al., 2008), cardiovascular diseases (Kardinaal et al., 1997, Oropeza-Moe et al., 2015), cancer, viral diseases (Clark et al., 1996, Beck et al., 2003), inflammatory conditions, diabetes mellitus, hepatopathies and HIV infection (Holben and Smith, 1999, Burk et al., 2015). Under this scenario, boifortification offers a cost 
effective and sustainable strategy in modern agriculture to allow the access of more nutritious and healthy food to large population (Bouis et al., 2011, Carvalho and Vasconcelos, 2013).

Biofortification is the process of increasing the bioavailable micronutrient density of staple crops through conventional plant breeding and modern biotechnology to achieve a measureable and positive impact on human health (Pfeiffer and McClafferty, 2007). Such an intervention can be used to enhance the uptake and accumulation of specific nutrients in edible part of plants (Rouached, 2013). It is attained through genetic engineering, conventional breeding and manipulation of agricultural practices such as rhizosphere fertilization, soil and crop management strategies (Zuo and Zhang, 2011) etc. Selenium is a vital micronutrient for human beings and animals (Hartikainen, 2005, Lobanov et al., 2008). Plant based foods are significant nutritional sources of selenium (Se) supply for both human beings and livestock to meet their daily requirement for selenium. For adults, daily consumption of 40 to $50 \mu \mathrm{g}$ selenium for women to $75 \mu \mathrm{g}$ for men and 8.7-10 $\mu \mathrm{g}$ for infants is recommended and an intake exceeding $400 \mu \mathrm{g} / \mathrm{day}$ is assumed to be toxic (Burk, 2002, Fordyce, 2013). Selenium poisoning, referred to as selenosis is related to dietary intake of approximately $5 \mathrm{mg}$ of selenium per day. In 1960, an outbreak of endemic human selenosis was reported in China, associated with the consumption of food containing more than $300 \mathrm{mg} / \mathrm{Kg}$ selenium (Fordyce, 2013). In almost all European countries, the selenium fortified foods and the use of dietary selenium supplements are quite popular to overcome the Se deficiency (Yadav et al., 2007).

To overcome the animal Se deficiency, different practices are commonly employed, e.g., the use of dietary supplements, injections, salt licks and drenches (Yadav et al., 2007). Alternatively, consumption of selenium enriched plants and their products is beneficial because selenium present in organic form is more bioavailable than in inorganic form (Terry et al., 2000, Li et al., 2017). The process of selenium accumulation in agricultural plants varies according to the plant species, soil properties and the chemical nature of selenium (Mikkelsen et al., 1989).Vegetable crops belonging to the Allium family (Allium sativum, Allium cepa, etc) are important part of the human daily diet. Biofortification of the vegetables, known as seleniferous plants, can contribute to the alleviation of selenium deficiency. Among these alliaceous species, garlic is one of the most popular vegetables around the globe (Ghasemi et al., 2015). In 2007 according to FAO (United Nations Food and Agriculture Organization), approximately 1.01 million hectare of land was used to produce about 10 million metric tons of garlic annually in the world. China is the largest producer of garlic, accounting more than $75 \%$ of the global production (Chen et al., 2013). Allium sativum has the ability to uptake the inorganic Se from the soil through the roots and is able to convert it into organic forms that are accumulated in its edible parts (Yadav et al., 2007). The chemistry of selenium in seleniferous plants simply relates to sulfur chemistry because selenium share great likeness in its chemical properties with sulfur and exists in oxidation states as elemental selenium $\left(\mathrm{Se}^{0}\right)$, selenide $\left(\mathrm{Se}^{2-}\right)$, selenite $\left(\mathrm{Se}^{4+}\right)$ and selenate $\left(\mathrm{Se}^{6+}\right)$. Within biological systems, selenium is incorporated as a constituent of selenocysteine (SeCys) and selenomethionine (SeMet) amino acids during translation of primary structure that comprise selenoprotiens. They are stored in the form of selenium methylselenocysteine (SeMSC) in seleniferous plants including garlic, Indian mustard (Brassica juncea L.), onion (Allium cepa), broccoli (Brassica oleraceae L.), sugar beet (Beta vulgaris L.)etc (Zayed et al., 1998, Fordyce, 2013). The main available form of 
selenium to plants is sodium selenate which is actively taken up by seleniferous plants through sulfate transporter and assimilated as organic form (SeMet and SeCys) with the help of enzymes, including ATP reductase, ATP sulfurylase, SeCys-lyase and O-acetyl serine transferase (Figure 1A) (Adhikari, 2012).

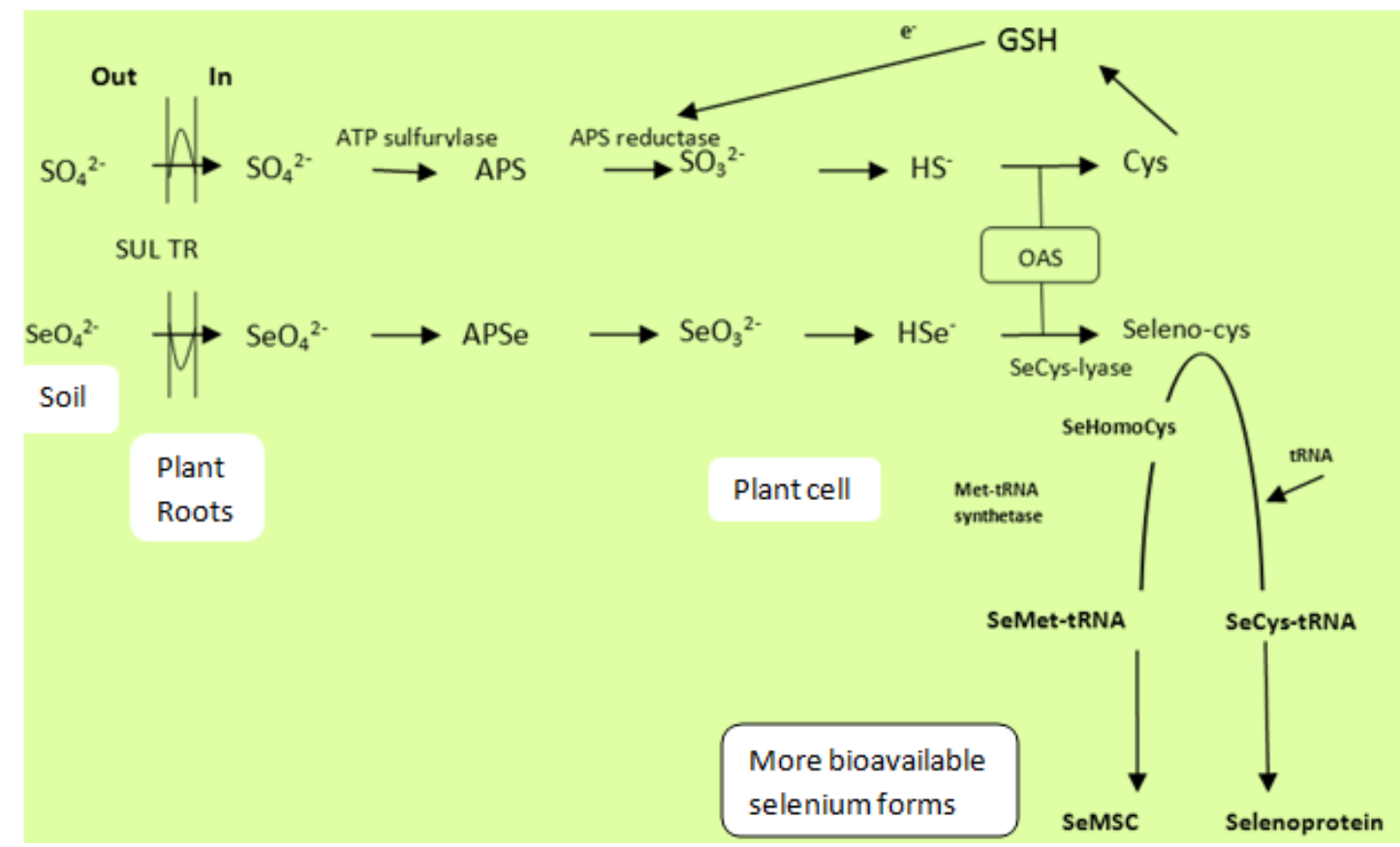

Figure 1A. Flow diagram showing sulfur and selenate uptake and assimilation pathway in seleniferous plants. SeCys-lyase is the enzyme that is highly specific to selenium substrate.

Sulfate transporter (SULTR), 5' adenylylsulfate (APS), 5' adenylylselenate (APS), $O$ acetylserine (Rehse et al., 2016)

In the past few decades, interest of scientists in naturally occurring compounds that act as antioxidants and regarding particularly dietary selenoenzymes has been increasing. Selenoenzymes play a vital role in protecting the body from oxidative damage/harmful effects of reactive oxygen species (ROS) and contain one or more unpaired electrons (Birringer et al., 2002). ROS are produced either from external sources, such as chemicals/pollution, or from internal sources e.g. aerobic respiration. They react quickly with other compounds and a chain reaction starts as the other molecule loses electrons and becomes a free radical. The result is the oxidation of vital cellular parts like DNA and proteins, the disintegration of cell membrane that lead to diseases (Kaur and Kapoor, 2002). In human beings, important selenoproteins(also known as selenoenzymes) are catalase, glutathione peroxidase (GPx) and superoxide dismutase which act as antioxidant and protect cells from ROS (Steinbrenner and Sies, 2009). Allium sativum is a natural source of various bioactive phytomolecules, including selenoproteins, allyl thiosulfinates, flavonoids, organosulfur compounds, phenolic acids and vitamins (Choi et al., 2014). Previous studies have reported on the health-promoting benefits of garlic because of its biologically active phenolic compounds with interesting medicinal properties (González-Morales et al., 2017). The extract of garlic has a remarkable antioxidant capacity and provides protection from oxidative DNA damage (Park et al., 2009), decreases the risk of chronic diseases, 
mitigates atherosclerosis and cancer (Morihara et al., 2010) etc. The objective of this study is to enrich garlic with selenium through biofortification, to analyze its impact on garlic quality parameters including phytochemical content and biological potential as free radical scavenging property. Additionally, there is possibility to introduce the selected garlic species for selenium phytoextraction in to selenium laden soils of Punjab Pakistan.

\section{Materials and Methods}

\section{Site description and Experimental design}

A field experiment was conducted at botanical garden of PCSIR Labs Complex, Lahore, Pakistan. Local garlic variety was sown season in January 2016 and harvested in May 2016. The experimental site is situated between $31.52^{\circ}$ North latitude, $74.33^{\circ}$ East longitude at the altitude of $217 \mathrm{~m}$ above sea level. A randomized complete block (RCB) design with three replicates was used with two factors (conc. of selenium salt applied and way of applications). Garlic sets were planted in the field divided into five plots. Treatments were control (no selenium application), selenium foliar spray and selenium soil flooding and two selenium salt concentrations $(20 \mathrm{~g} / \mathrm{ha}$ and $50 \mathrm{~g} / \mathrm{ha})$. Standard agronomic practices were used. The size of each individual plot was $2 \mathrm{~m}$ length $x 3.66 \mathrm{~m}$ width $=29.28 \mathrm{~m}^{2}$, with a density of 15 plants per square meter. Each plot was consisted of 11 rows, with 6 plants in each row and the distance between rows was $0.65 \mathrm{~m}$. A basal dose of N-P-K in ratio of $11-5-18 \mathrm{~kg} / \mathrm{ha}$ was applied prior to planting. Melathion was sprayed as a herbicide after 8 weeks of sowing.

\section{Chemicals}

All chemicals were analytical grade. sodium selenate, Folin Ciocaltaeu reagent, ascorbic acid, butylated hydroxyl Toluene (BHT), sodium carbonate, aluminium chloride potassium acetate, quercetin and gallic acid were purchased from sigma aldrich chemical Co (St.Louis, MO, USA). DPPH dye was purchased from Alfa Aesar, Germany. Ethanol, hydrochloric acid, dimethylsulphoxide (DMSO), methanol were obtained from Merck (Darmstadt, Germany).

\section{Selenium treatments}

Selenium was applied as sodium selenate $\left(\mathrm{Na}_{2} \mathrm{SeO}_{4}\right)$ in the experimental field. Aqueous sodium selenate solution $(1.0 \mathrm{~g} /$ Liter $)$ was applied at the concentration of $20 \mathrm{~g} / \mathrm{ha}$ ) and $50 \mathrm{~g} / \mathrm{ha}$ in two ways i.e. by foliar spray and through water flooding in selected plots. First application was carried out on day 9 and afterward 30 days interval from sowing, during whole growing season (Figure 1B). Garlic crop was harvested in May after $120 \pm 2$ days of growth.

\section{Preparation of sample}

Finely ground sample $0.5 \mathrm{~g}$ was accurately weighed in a china crucible. The sample was kept in the muffle furnace at $500^{\circ} \mathrm{C}$ for $4-6$ hours or until white ash is formed. The ash was dissolved in $5 \mathrm{ml}$ of $6 \mathrm{~N} \mathrm{HCl}$ by heating on a hot plate, filtered through Whatman no.1 filter paper and the final volume was made up to $100 \mathrm{ml}$ with double distilled water (AOAC, 1990). 


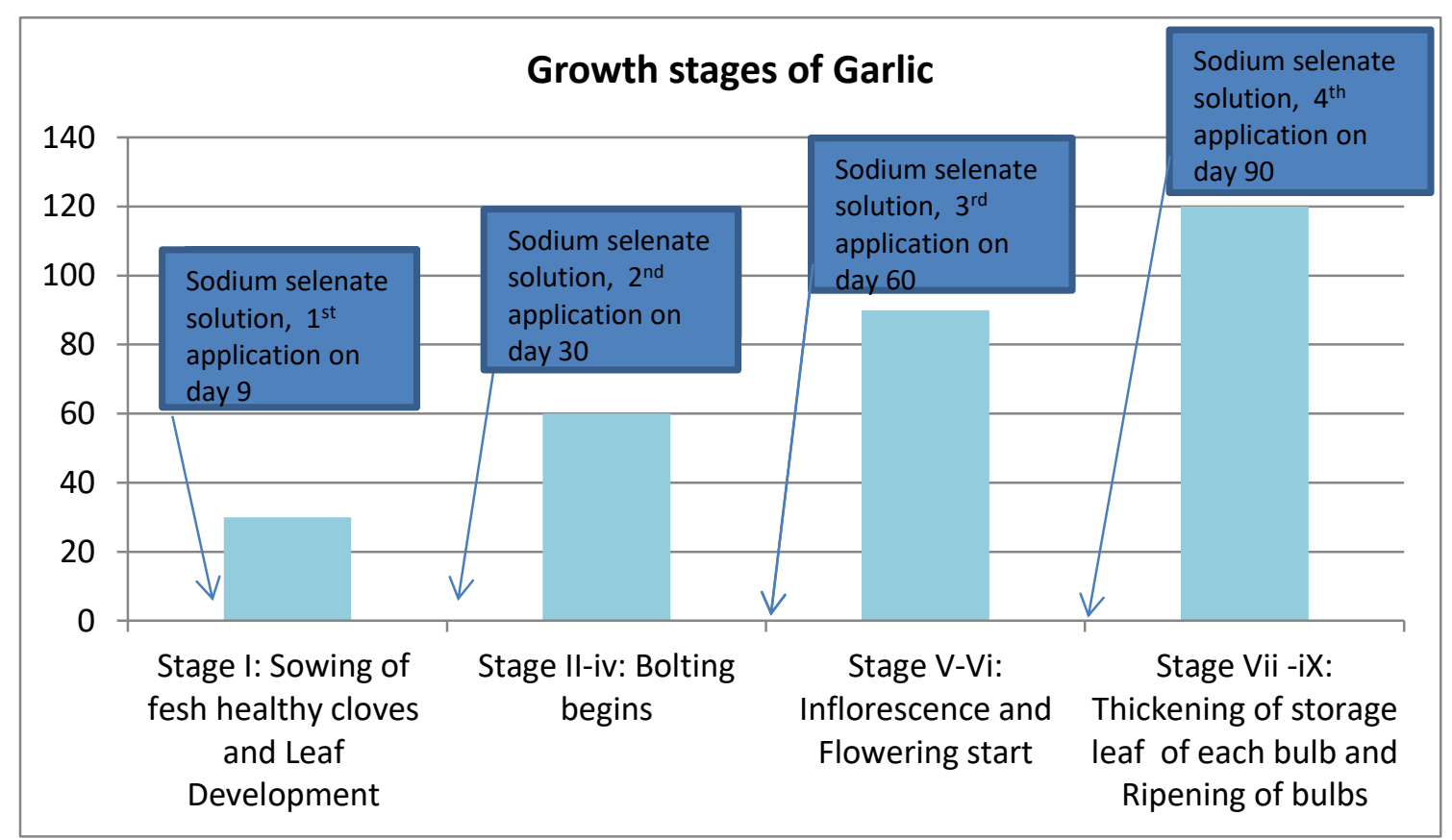

Figure 1B. General symbolic representation of growth stages of garlic (I to ix) along with selenium application at various time periods. Information related to garlic growth stages was obtained from Meier et al. (2009)

\section{Determination of selenium by inductively coupled plasma-mass spectrometer using dynamic reaction cell}

Shimadzu Sequential type plasma Emission Spectrometer model ICPS-1000 111 and JY 24 spectroanalyzer (ICP-MS) was used for the determination of Se. A glass Meinhard nebulizer and a glass cyclonic spray chamber were used to introduce the sample. Experimental Instrument Conditions were RF Power 1200 watts, plasma gas flow $15 \mathrm{~L} \mathrm{~min}^{-1}$,auxiliary gas flow $1.2 \mathrm{Lmin}^{-1}, \mathrm{RPq} 0.5$, cell gas $\left(\mathrm{O}_{2}\right)$ flow rate(DRC) 0.4 $\mathrm{Lmin}^{-1}$. A series of standards containing selenium $(0.01-0.5 \mathrm{mg} / \mathrm{L})$ were prepared from standard stock solution of Se $(1000 \pm 2 \mathrm{mg} / \mathrm{L}$, Merck, Darmstadt, Germany), and used to calibrate instrument. Standard solutions of Selenium with 1.0 to $50 \mathrm{mg} \mathrm{L}^{-1}$ were used for quantification. Method validation was performed by analyzing three replicates of artificially spiked garlic powder with a final concentration of $5 \mathrm{mg} / \mathrm{kg}$ of selenium. A standard deviation of $0.05 \mathrm{mg} / \mathrm{kg}$ and coefficient of variation of $2.71 \%$ was obtained with a recovery of $97 \%$. The limit of detection ( $L O D=3 \mathrm{SD})$ as calculated by the Eurachem Guide (Guide, 1998) was $0.15 \mathrm{mg} / \mathrm{kg}$. Measurement of uncertainty of the method $(\mathrm{K}=2)$ was 0.03 .

\section{Phytochemical analysis}

An appropriate amount $(20 \mathrm{~g})$ of garlic foliar mass and bulb powder were separately extracted in $80 \%$ ethanol by stirring at $25^{\circ} \mathrm{C}$ for $24 \mathrm{~h}$ in closed vessel system, according to the method described by Peschel et al. (2006) with minor modification. After solvent evaporation under vacuum, extracts were resuspended in DMSO and stored at $4{ }^{\circ} \mathrm{C}$. 


\section{Estimation of total phenolic content (TPC)}

Total phenolic content of each treatment (garlic bulb \& foliar mass) were determined by using Folin Ciocalteu reagent for color development along with sodium carbonate, by following the method with slight modifications reported by Singleton and Rossi (1965). Absorbance of developed blue coloured complex was taken at $755 \mathrm{~nm}$ with a spectrophotometer (Nicolet, Evlution-300, Germany). TPC of extracts was quantified through the standard curve of gallic acid $\left(\mathrm{r}^{2}=0.9972\right)$. The results are given in $\mathrm{mg}$ gallic acid equivalent (GAE)/ $100 \mathrm{~g}$ of dry wt.

\section{Estimation of total flavonoid content (TFC)}

Total flavonoid content was estimated by using aluminum chloride colorimetric method (Chang et al., 2002). Appropriate quantity $(100 \mu 1)$ of each sample extract was taken and mixed with suitable amount of methanol, $10 \%$ aluminum chloride and $1 \mathrm{M}$ potassium acetate for development of coloured complex. After 30 minutes of incubation period, absorbance of the developed colour was taken at $415 \mathrm{~nm}$ with a spectrophotometer. Quercetin standard curve $\left(\mathrm{r}^{2}=0.9985\right)$ was used for the quantification of TFC of experimental samples and expressed in $\mathrm{mg}$ quercetin equivalent (QE) /100g of dry wt.

\section{In vitro 2, 2-diphenyl-1-picrylhydrazyl radical scavenging activity}

In current study the hydrogen atoms donating capacity of garlic leaves and bulb extracts were determined through DPPH free radical assay (Brand-Williams et al., 1995). Ethanolic solutions of each extract were prepared in the range of $0.02 \mathrm{mg} / \mathrm{ml}$ to $0.1 \mathrm{mg} / \mathrm{ml}$, following the mixing of ethanolic dilutions of extract (100 $\mu \mathrm{l} \mathrm{each)} \mathrm{with}$ DPPH $(0.1 \mathrm{mM})$ solution. BHT (Butylated hydroxytoluene) and Ascorbic Acid were used as positive controls. After an incubation period of 30 minutes in the dark at ambient temperature, absorbance of reaction mixtures were taken at $517 \mathrm{~nm}$ through UV-spectrophotometer. Finally, duplicate measurements were taken and percentage DPPH radical scavenging ability was calculated by using Equation 1.

$$
D P P H \text { scavenging activity }(\%)=\left\{\left(A b s_{\cdot_{(\text {control })}}-A b s_{\cdot_{(\text {sample })}} / A b s_{\cdot_{(\text {control })}}\right\} \times 100\right. \text { (Eq. 1) }
$$

where Abs. (control) was absorbance of DPPH radical + ethanol and Abs. (sample) was absorbance of DPPH radical + sample.

\section{Statistical analysis}

All data are presented as mean $\pm \mathrm{SD}$. The calculated mean values were based on the data obtained from at least three independent experiments. Two ways Analysis of Variance (Webb et al., 2012) was performed by Graph pad Prism 5 at a confidence interval of $95 \%$ to see the significant difference among results (GraphPad Software). Results showing probability value of $<0.05$ were considered to be statistically significant. 


\section{Results}

\section{Fresh weight yield $\mathrm{m}^{-2}$, dry matter and climatic conditions}

Observations were taken for the fresh weight of plantlets both in the case of control set as well as those treated after harvest, which showed that maximum fresh wt. yield of garlic plants was obtained in treatment III $\left(1723 \pm 32.12 \mathrm{~g} / \mathrm{m}^{2}\right)$ and minimum in treatment II $\left(1653 \pm 25.86 \mathrm{~g} / \mathrm{m}^{2}\right)$ in comparison to control plants $\left(1650 \pm 33.82 \mathrm{~g} / \mathrm{m}^{2}\right)$. Present results were non significantly different $(\mathrm{P}>0.05)$ in total fresh weight yield per square meter as shown in Figure 2. Dry matter of garlic plants enhanced as the concentration of selenium salt was increased. The highest amount of dry matter was obtained in treatment III $(13.49 \pm 0.71 \%)$ and treatment I $(13.01 \pm 2.46 \%)$ which were non significantly different $(\mathrm{P}>0.05)$ from control $(12.12 \pm 1.57 \%)$ (Figure 3 and Table 1).

Table 1. ANOVA for fresh weight yield of garlic

\begin{tabular}{|c|c|c|c|c|}
\hline Source of Variation & \multicolumn{2}{|c|}{$\%$ of total variation } & \multicolumn{2}{|c|}{ P value } \\
\hline Interaction & \multicolumn{2}{|c|}{0.00} & \multicolumn{2}{|c|}{1.0000} \\
\hline $\mathrm{t}$ & \multicolumn{2}{|c|}{75.13} & \multicolumn{2}{|c|}{0.0045} \\
\hline $\mathrm{p}$ & \multicolumn{2}{|c|}{0.00} & \multicolumn{2}{|c|}{1.0000} \\
\hline Source of Variation & \multicolumn{2}{|c|}{ P value summary } & \multicolumn{2}{|c|}{ Significant? } \\
\hline Interaction & \multirow{2}{*}{\multicolumn{2}{|c|}{$\begin{array}{l}\mathrm{ns} \\
* *\end{array}$}} & \multicolumn{2}{|c|}{ No } \\
\hline $\mathrm{t}$ & & & \multirow{2}{*}{\multicolumn{2}{|c|}{ Yes }} \\
\hline $\mathrm{p}$ & \multicolumn{2}{|c|}{$\mathrm{ns}$} & & \\
\hline Source of Variation & Df & Sum-of-squares & Mean square & $\mathbf{F}$ \\
\hline Interaction & 4 & 0.0000 & 0.0000 & 0.0000 \\
\hline $\mathrm{t}$ & 4 & 5203 & 1301 & 7.553 \\
\hline $\mathrm{p}$ & 1 & 0.0000 & 0.0000 & 0.0000 \\
\hline Residual & 10 & 1722 & 172.2 & \\
\hline Number of missing values & 0 & & & \\
\hline \multicolumn{5}{|c|}{ Bonferroni posttests } \\
\hline \multicolumn{5}{|c|}{ Control vs Treatment I } \\
\hline $\mathbf{p}$ & Control & Treatment I & Difference & $95 \%$ CI of diff. \\
\hline fresh wt.yeild $\mathrm{g}^{\prime}$ & 1664 & 1696 & 31.50 & -13.74 to 76.74 \\
\hline fresh wt.yeild $\mathrm{g} / \mathrm{m} 2$ & 1664 & 1696 & 31.50 & -13.74 to 76.74 \\
\hline $\mathbf{p}$ & Difference & $\mathbf{t}$ & $P$ value & Summary \\
\hline fresh wt.yeild $\mathrm{g} / \mathrm{m} 2$ & 31.50 & 2.400 & $P>0.05$ & $\mathrm{~ns}$ \\
\hline fresh wt.yeild $\mathrm{g} / \mathrm{m} 2$ & 31.50 & 2.400 & $P>0.05$ & ns \\
\hline \multicolumn{5}{|c|}{ Control vs Treatment II } \\
\hline $\mathbf{p}$ & Control & Treatment II & Difference & $95 \%$ CI of diff. \\
\hline fresh wt.yeild $\mathrm{g}^{\prime}$ & 1664 & 1661 & -3.000 & -48.24 to 42.24 \\
\hline fresh wt.yeild $\mathrm{g} / \mathrm{m} 2$ & 1664 & 1661 & -3.000 & -48.24 to 42.24 \\
\hline $\mathbf{p}$ & Difference & $\mathbf{t}$ & P value & Summary \\
\hline fresh wt.yeild $\mathrm{g} / \mathrm{m} 2$ & -3.000 & 0.2286 & $\mathrm{P}>0.05$ & $\mathrm{~ns}$ \\
\hline fresh wt.yeild $\mathrm{g} / \mathrm{m} 2$ & -3.000 & 0.2286 & $P>0.05$ & $\mathrm{~ns}$ \\
\hline \multicolumn{5}{|c|}{ Control vs Treatment III } \\
\hline $\mathbf{p}$ & Control & Treatment III & Difference & $95 \%$ CI of diff. \\
\hline fresh wt.yeild $\mathrm{g}^{\prime}$ & 1664 & 1700 & 36.00 & -9.243 to 81.24 \\
\hline fresh wt.yeild $\mathrm{g} / \mathrm{m} 2$ & 1664 & 1700 & 36.00 & -9.243 to 81.24 \\
\hline p & Difference & $\mathbf{t}$ & P value & Summary \\
\hline fresh wt.yeild $\mathrm{g} / \mathrm{m} 2$ & 36.00 & 2.743 & $\mathrm{P}<0.05$ & $*$ \\
\hline fresh wt.yeild $\mathrm{g} / \mathrm{m} 2$ & 36.00 & 2.743 & $\mathrm{P}<0.05$ & * \\
\hline \multicolumn{5}{|c|}{ Control vs Treatment IV } \\
\hline p & Control & Treatment IV & Difference & $95 \%$ CI of diff. \\
\hline fresh wt.yeild $\mathrm{g}^{\prime}$ & 1664 & 1688 & 23.50 & -21.74 to 68.74 \\
\hline fresh wt.yeild $\mathrm{g} / \mathrm{m} 2$ & 1664 & 1688 & 23.50 & -21.74 to 68.74 \\
\hline p & Difference & $\mathbf{t}$ & P value & Summary \\
\hline fresh wt.yeild $\mathrm{g} / \mathrm{m} 2$ & 23.50 & 1.791 & $P>0.05$ & $\mathrm{~ns}$ \\
\hline fresh wt.yeild $\mathrm{g} / \mathrm{m} 2$ & 23.50 & 1.791 & $P>0.05$ & ns \\
\hline
\end{tabular}




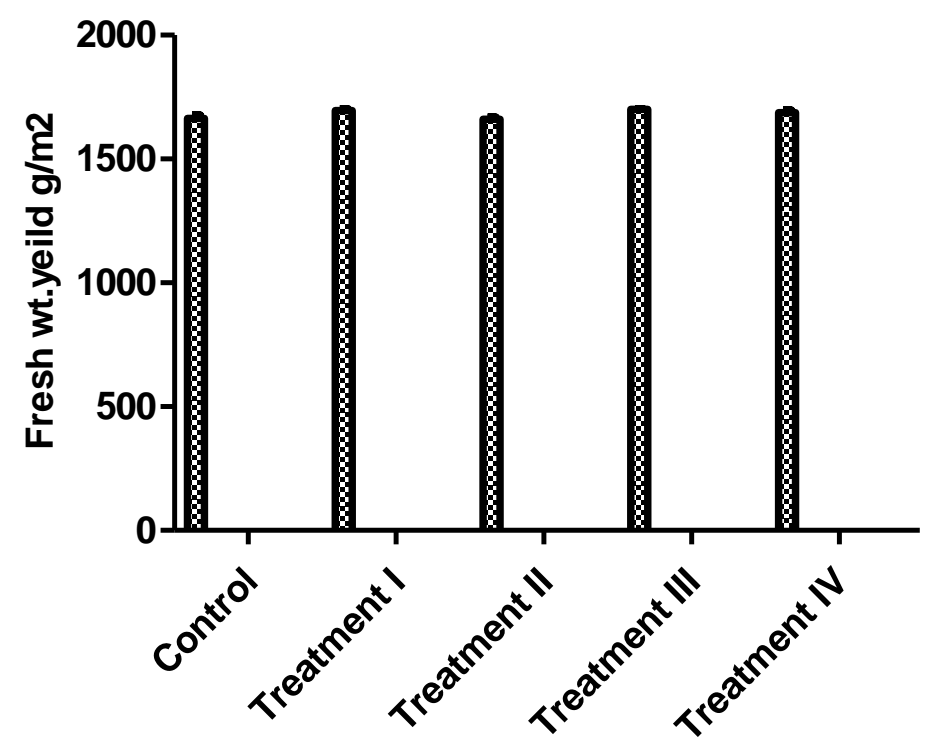

Figure 2. Total fresh wt. yield of variously treated garlic plants. Error bars indicate standard error of the mean

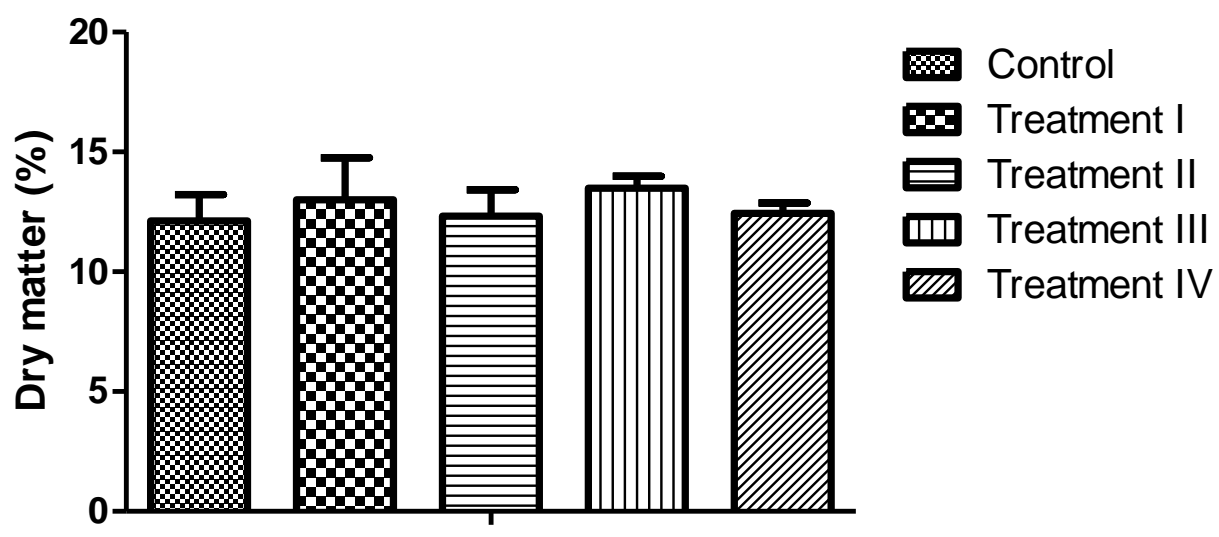

whole plant (bulb+ foliar part)

Figure 3. Dry matter content in percentage for all four treatments and control garlic plant. Error bars indicate standard error of the mean

Data related to monthly mean temperature $\left({ }^{\circ} \mathrm{C}\right)$ and mean rainfall $(\mathrm{mm})$ from the period of transplanting to harvest was collected from Pakistan Meteorological department (PMD), Lahore, Pakistan. The monthly average rainfall, maximum and minimum temperature for the garlic field location during the whole growing season were $0.62 \mathrm{~mm}, 29.05{ }^{\circ} \mathrm{C}$ and $16.13{ }^{\circ} \mathrm{C}$ respectively (Figure 4). 


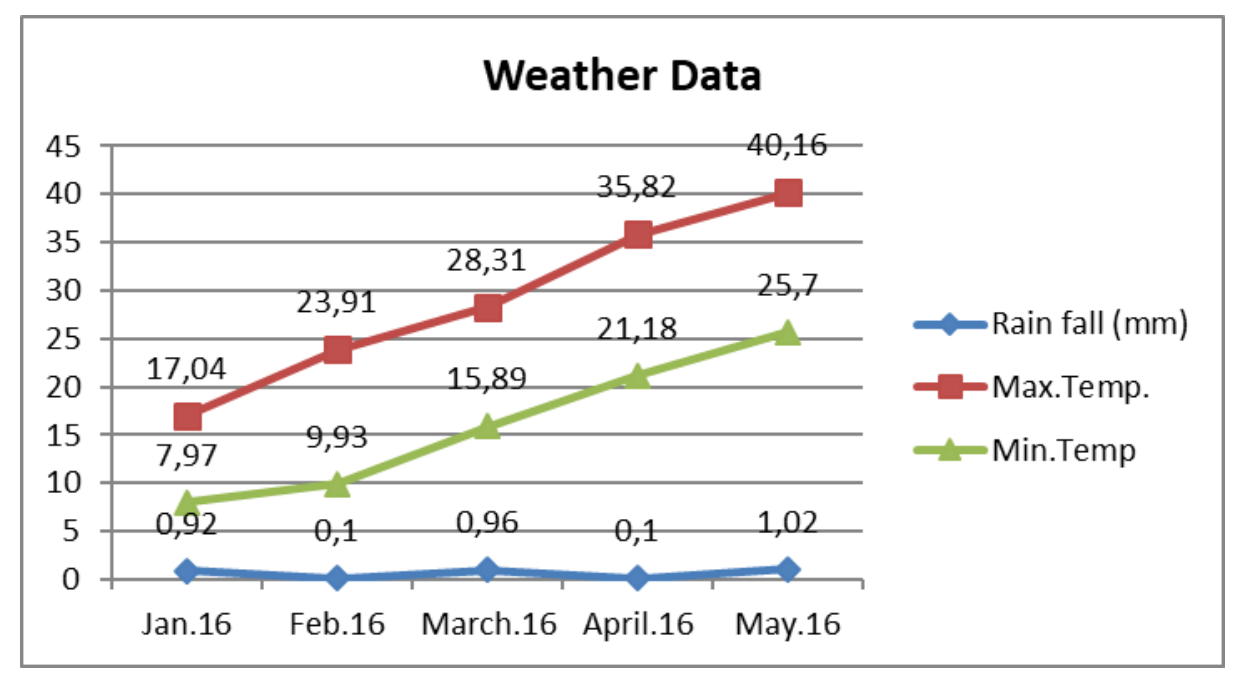

Figure 4. Monthly average rainfall, maximum and minimum temperature recorded at local weather station during growing season

\section{Selenium content}

Total selenium content of plant samples was determined by ICP-MS. Current results depicted that $\mathrm{Se}$ concentration was enhanced with increasing fertilization for all treatments. However, foliar application was found to be most effective in garlic selenium enrichment as compared to soil application (Figure 5). The highest average selenium concentration $3.23 \pm 0.16 \mathrm{mgSeKg}^{-1}$ in bulbs and $15.46 \pm 0.71 \mathrm{mgSeKg}_{-}{ }^{1}$ in garlic vegetative part were observed in treatment III in comparison to control plant exhibiting $0.369 \pm 0.078 \mathrm{mgSeKg}^{-1}$ in bulbous part and $4.96 \pm 0.49 \mathrm{mgSeKg}^{-1}$ in vegetative part, respectively (Table 2).

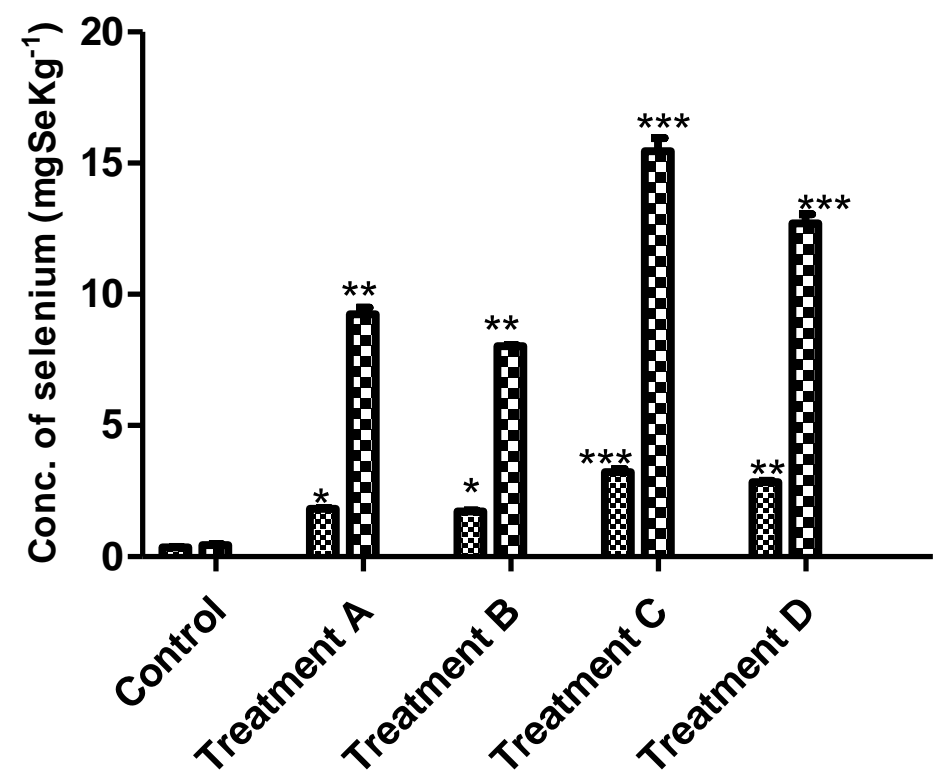

\section{\% Garlic Bulbs \\ at Garlic leaves}

Figure 5. Selenium concentration in foliar part and bulbs of Allium sativum subjected to four various Se treatments. Error bars indicate standard error of the mean. (*) significantly different at $P<0.05$. (**) significantly different at $P<0.01$. (***) significantly different at $P<0.001$ 
Table 2. ANOVA for selenium estimation in garlic

\begin{tabular}{|c|c|c|c|c|}
\hline Source of Variation & \multicolumn{2}{|c|}{ \% of total variation } & \multicolumn{2}{|c|}{ P value } \\
\hline Interaction & \multicolumn{2}{|c|}{15.89} & \multicolumn{2}{|c|}{$<0.0001$} \\
\hline $\mathrm{t}$ & \multicolumn{2}{|c|}{48.81} & \multicolumn{2}{|c|}{$<0.0001$} \\
\hline $\mathrm{p}$ & \multicolumn{2}{|c|}{35.12} & \multicolumn{2}{|c|}{$<0.0001$} \\
\hline Source of Variation & \multicolumn{2}{|c|}{ P value summary } & \multicolumn{2}{|c|}{ Significant? } \\
\hline Interaction & \multicolumn{2}{|c|}{$* * *$} & \multicolumn{2}{|c|}{ Yes } \\
\hline $\mathrm{t}$ & \multicolumn{2}{|c|}{$* * *$} & \multicolumn{2}{|c|}{ Yes } \\
\hline $\mathrm{p}$ & \multicolumn{2}{|c|}{$* * *$} & \multicolumn{2}{|c|}{ Yes } \\
\hline Source of Variation & Df & Sum-of-squares & Mean square & $\mathbf{F}$ \\
\hline Interaction & 4 & 83.83 & 20.96 & 229.1 \\
\hline $\mathrm{t}$ & 1 & 257.5 & 257.5 & 2815 \\
\hline $\mathrm{p}$ & 4 & 185.3 & 46.32 & 506.4 \\
\hline Residual & 10 & 0.9146 & 0.09146 & \\
\hline Number of missing values & 30 & & & \\
\hline \multicolumn{5}{|c|}{ Bonferroni posttests } \\
\hline \multicolumn{5}{|c|}{ Garlic Bulbs vs Garlic leaves } \\
\hline $\mathbf{t}$ & Garlic Bulbs & Garlic leaves & Difference & $95 \%$ CI of diff. \\
\hline Control & 0.3550 & 0.4450 & 0.0900 & -1.121 to 1.301 \\
\hline Treatment A & 1.828 & 9.240 & 7.413 & 6.201 to 8.624 \\
\hline Treatment B & 1.732 & 8.020 & 6.289 & 5.077 to 7.500 \\
\hline Treatment $\mathrm{C}$ & 3.225 & 15.46 & 12.24 & 11.02 to 13.45 \\
\hline Treatment D & 2.850 & 12.71 & 9.855 & 8.644 to 11.07 \\
\hline $\mathbf{t}$ & Difference & t & P value & Summary \\
\hline Control & 0.0900 & 0.2976 & $P>0.05$ & $\mathrm{~ns}$ \\
\hline Treatment A & 7.413 & 24.51 & $\mathrm{P}<0.001$ & $* * *$ \\
\hline Treatment B & 6.289 & 20.79 & $\mathrm{P}<0.001$ & $* * *$ \\
\hline Treatment $\mathrm{C}$ & 12.24 & 40.46 & $\mathrm{P}<0.001$ & $* * *$ \\
\hline Treatment D & 9.855 & 32.59 & $\mathrm{P}<0.001$ & $* * *$ \\
\hline
\end{tabular}

\section{Total phenolic content (TPC)}

Total phenolic content of all treated and control garlic samples exhibited significant results (Figure 6). The results showed that higher phenolic content are present in treatment III vegetative part $(23.46 \pm 2.12 \mathrm{mg}$ GAE$/ 100 \mathrm{~g}$ dry wt) followed by treatment IV (21.71 $\pm 0.51 \mathrm{mg}$ GAE/100g dry wt), treatment I (19.24 $\pm 0.35 \mathrm{mgGAE} / 100 \mathrm{~g}$ dry wt) and treatment II $(18.82 \pm 1.17 \mathrm{mgGAE} / 100 \mathrm{~g}$ dry $\mathrm{wt})$ vegetative part, respectively. Treatment III was more effective for enhancing TPC of garlic bulbs i.e. $4.72 \pm 1.79$ mgGAE/100g dry wt (1.82 fold increase) in comparison to control containing total phenolic content of $2.59 \pm 0.707 \mathrm{mgGAE} / 100 \mathrm{~g}$ dry wt which are significantly different from each other (Table 3).

Table 3. ANOVA for total phenolic contents in garlic

\begin{tabular}{|c|c|c|c|c|}
\hline Source of Variation & \multicolumn{2}{|c|}{ \% of total variation } & \multicolumn{2}{|c|}{ P value } \\
\hline Interaction & \multicolumn{2}{|c|}{0.39} & \multicolumn{2}{|c|}{0.3750} \\
\hline $\mathrm{t}$ & \multicolumn{2}{|c|}{2.53} & \multicolumn{2}{|c|}{0.0044} \\
\hline $\mathrm{p}$ & \multicolumn{2}{|c|}{96.26} & \multicolumn{2}{|c|}{$<0.0001$} \\
\hline Source of Variation & \multicolumn{2}{|c|}{ P value summary } & \multicolumn{2}{|c|}{ Significant? } \\
\hline Interaction & \multirow{2}{*}{\multicolumn{2}{|c|}{$\mathrm{ns}$}} & \multicolumn{2}{|c|}{ No } \\
\hline $\mathrm{t}$ & & $\begin{array}{l}* * \\
* * *\end{array}$ & \multicolumn{2}{|c|}{ Yes } \\
\hline $\mathrm{p}$ & \multicolumn{2}{|c|}{$* * *$} & \multicolumn{2}{|c|}{ Yes } \\
\hline Source of Variation & Df & Sum-of-squares & Mean square & $\mathbf{F}$ \\
\hline Interaction & 4 & 5.872 & 1.468 & 1.184 \\
\hline $\mathrm{t}$ & 4 & 37.85 & 9.462 & 7.635 \\
\hline $\mathrm{p}$ & 1 & 1442 & 1442 & 1164 \\
\hline Residual & 10 & 12.39 & 1.239 & \\
\hline Number of missing values & 0 & & & \\
\hline
\end{tabular}




\begin{tabular}{|c|c|c|c|c|}
\hline \multicolumn{5}{|c|}{ Bonferroni posttests } \\
\hline \multicolumn{5}{|c|}{ Control vs Treatment I } \\
\hline $\mathbf{p}$ & Control & Treatment I & Difference & $95 \%$ CI of diff. \\
\hline Garlic bulb & 2.590 & 2.940 & 0.3500 & -3.488 to 4.188 \\
\hline Garlic leaves & 18.54 & 19.24 & 0.7050 & -3.133 to 4.543 \\
\hline $\mathbf{p}$ & Difference & $\mathbf{t}$ & $P$ value & Summary \\
\hline Garlic bulb & 0.3500 & 0.3144 & $P>0.05$ & ns \\
\hline Garlic leaves & 0.7050 & 0.6333 & $\mathrm{P}>0.05$ & ns \\
\hline \multicolumn{5}{|c|}{ Control vs Treatment II } \\
\hline $\mathbf{p}$ & Control & Treatment II & Difference & $95 \%$ CI of diff. \\
\hline Garlic bulb & 2.590 & 2.640 & 0.05000 & -3.788 to 3.888 \\
\hline Garlic leaves & 18.54 & 18.82 & 0.2850 & -3.553 to 4.123 \\
\hline $\mathbf{p}$ & Difference & $\mathbf{t}$ & $P$ value & Summary \\
\hline Garlic bulb & 0.05000 & 0.04491 & $P>0.05$ & $\mathrm{~ns}$ \\
\hline Garlic leaves & 0.2850 & 0.2560 & $\mathrm{P}>0.05$ & ns \\
\hline \multicolumn{5}{|c|}{ Control vs Treatment III } \\
\hline $\mathbf{p}$ & Control & Treatment III & Difference & $95 \%$ CI of diff. \\
\hline Garlic bulb & 2.590 & 4.720 & 2.130 & -1.708 to 5.968 \\
\hline Garlic leaves & 18.54 & 23.46 & 4.925 & 1.087 to 8.763 \\
\hline $\mathbf{p}$ & Difference & $\mathbf{t}$ & P value & Summary \\
\hline Garlic bulb & 2.130 & 1.913 & $\mathrm{P}>0.05$ & ns \\
\hline Garlic leaves & 4.925 & 4.424 & $\mathrm{P}<0.01$ & $* *$ \\
\hline \multicolumn{5}{|c|}{ Control vs Treatment IV } \\
\hline p & Control & Treatment IV & Difference & $95 \%$ CI of diff. \\
\hline Garlic bulb & 2.590 & 3.950 & 1.360 & -2.478 to 5.198 \\
\hline Garlic leaves & 18.54 & 21.71 & 3.170 & -0.6682 to 7.008 \\
\hline p & Difference & $\mathbf{t}$ & P value & Summary \\
\hline Garlic bulb & 1.360 & 1.222 & $\mathrm{P}>0.05$ & ns \\
\hline Garlic leaves & 3.170 & 2.848 & $\mathrm{P}<0.05$ & $*$ \\
\hline
\end{tabular}

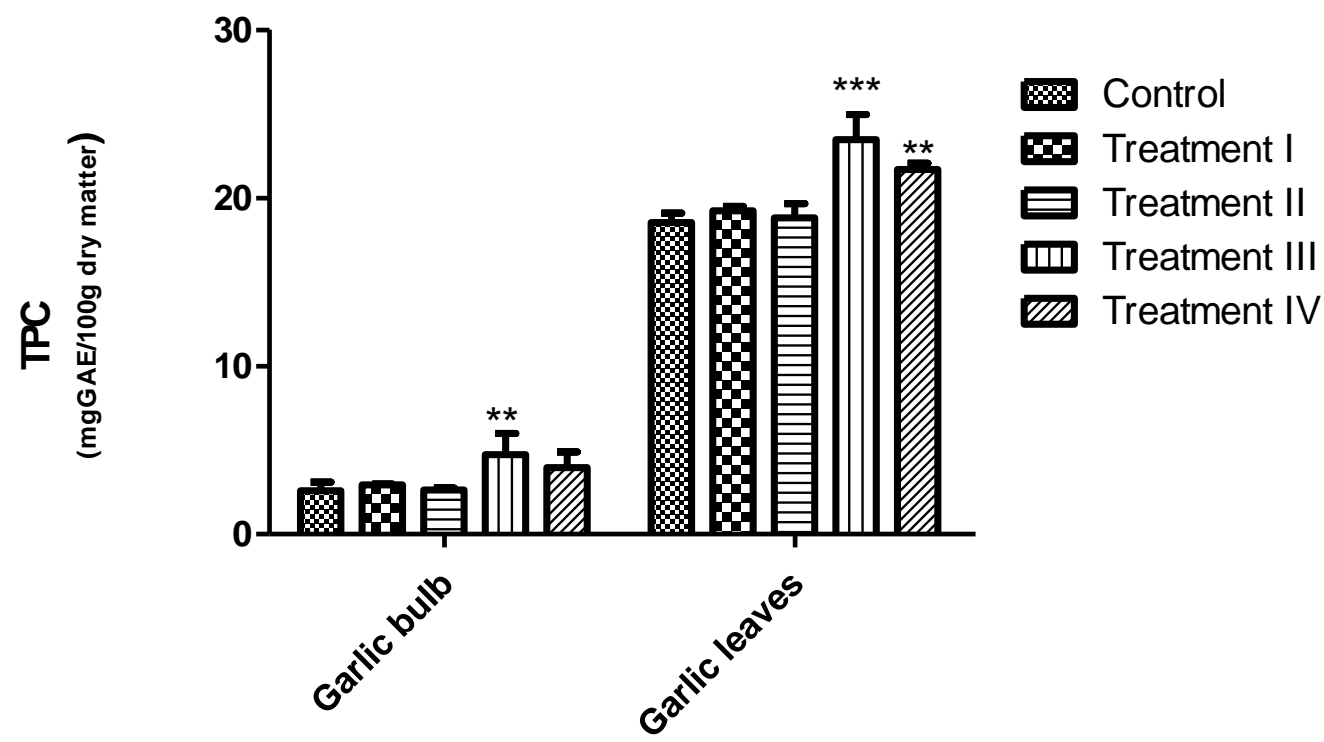

Figure 6. Estimation of total phenolic content in foliar part and bulbs of Allium sativum subjected to four various Se treatments. Error bars indicate standard error of the mean. (*) significantly different at $P<0.05$. (**) significantly different at $P<0.01$. (***) significantly different at $P<0.001$ 


\section{Total flavonoid content (TFC)}

Significantly $(\mathrm{P}>0.05)$ elevated amount of total flavonoid content were observed in Allium sativum leaves and bulb (Figure 7). Current results depicted that total Flavonoid content of treated A. sativum bulbs and leaves were in the range of $18.19 \pm 1.21$ to 18.50 $\pm 1.82 \mathrm{mgQE} / 100 \mathrm{~g}$ dry wt and $34.13 \pm 1.36$ to $34.99 \pm 1.54 \mathrm{mgQE} / 100 \mathrm{~g}$ dry wt, respectively in comparison to control bulb (11.32 $\pm 0.95 \mathrm{mgQE} / 100 \mathrm{~g}$ dry) and leaves (13.53 $\pm 0.76 \mathrm{mgQE} / 100 \mathrm{~g}$ dry wt. as in Table 4).

Table 4. ANOVA for total flavonoid contents in garlic

\begin{tabular}{|c|c|c|c|c|}
\hline Source of Variation & \multicolumn{2}{|c|}{$\%$ of total variation } & \multicolumn{2}{|c|}{ P value } \\
\hline Interaction & \multicolumn{2}{|c|}{9.20} & \multicolumn{2}{|c|}{$<0.0001$} \\
\hline $\mathrm{t}$ & \multicolumn{2}{|c|}{37.09} & \multicolumn{2}{|c|}{$<0.0001$} \\
\hline $\mathrm{p}$ & \multicolumn{2}{|c|}{52.77} & \multicolumn{2}{|c|}{$<0.0001$} \\
\hline Source of Variation & \multicolumn{2}{|c|}{ P value summary } & \multicolumn{2}{|c|}{ Significant? } \\
\hline Interaction & \multicolumn{2}{|c|}{$* * *$} & \multicolumn{2}{|c|}{ Yes } \\
\hline $\mathrm{t}$ & \multicolumn{2}{|c|}{$* * *$} & \multicolumn{2}{|c|}{ Yes } \\
\hline $\mathrm{p}$ & \multicolumn{2}{|c|}{$* * *$} & \multicolumn{2}{|c|}{ Yes } \\
\hline Source of Variation & Df & Sum-of-squares & Mean square & $\mathbf{F}$ \\
\hline Interaction & 4 & 155.9 & 38.99 & 24.46 \\
\hline $\mathrm{t}$ & 4 & 628.3 & 157.1 & 98.56 \\
\hline $\mathrm{p}$ & 1 & 894.1 & 894.1 & 561.0 \\
\hline Residual & 10 & 15.94 & 1.594 & \\
\hline Number of missing values & 0 & & & \\
\hline \multicolumn{5}{|c|}{ Bonferroni posttests } \\
\hline \multicolumn{5}{|c|}{ Control vs Treatment I } \\
\hline p & Control & Treatment I & Difference & $95 \%$ CI of diff. \\
\hline Garlic bulb & 11.32 & 18.43 & 7.115 & 2.762 to 11.47 \\
\hline Garlic leaves & 13.53 & 34.24 & 20.71 & 16.36 to 25.06 \\
\hline p & Difference & $\mathbf{t}$ & $P$ value & Summary \\
\hline Garlic bulb & 7.115 & 5.636 & $\mathrm{P}<0.001$ & $* * *$ \\
\hline Garlic leaves & 20.71 & 16.40 & $\mathrm{P}<0.001$ & $* * *$ \\
\hline \multicolumn{5}{|c|}{ Control vs Treatment II } \\
\hline $\mathbf{p}$ & Control & Treatment II & Difference & $95 \%$ CI of diff. \\
\hline Garlic bulb & 11.32 & 18.20 & 6.880 & 2.527 to 11.23 \\
\hline Garlic leaves & 13.53 & 34.13 & 20.60 & 16.25 to 24.95 \\
\hline p & Difference & $\mathbf{t}$ & P value & Summary \\
\hline Garlic bulb & 6.880 & 5.450 & $\mathrm{P}<0.001$ & $* * *$ \\
\hline Garlic leaves & 20.60 & 16.32 & $\mathrm{P}<0.001$ & $* * *$ \\
\hline \multicolumn{5}{|c|}{ Control vs Treatment III } \\
\hline p & Control & Treatment III & Difference & $95 \%$ CI of diff. \\
\hline Garlic bulb & 11.32 & 18.50 & 7.185 & 2.832 to 11.54 \\
\hline Garlic leaves & 13.53 & 34.99 & 21.46 & 17.11 to 25.81 \\
\hline $\mathbf{p}$ & Difference & $\mathbf{t}$ & P value & Summary \\
\hline Garlic bulb & 7.185 & 5.691 & $\mathrm{P}<0.001$ & $* * *$ \\
\hline Garlic leaves & 21.46 & 17.00 & $\mathrm{P}<0.001$ & $* * *$ \\
\hline \multicolumn{5}{|c|}{ Control vs Treatment IV } \\
\hline $\mathbf{p}$ & Control & Treatment IV & Difference & $95 \%$ CI of diff. \\
\hline Garlic bulb & 11.32 & 18.26 & 6.945 & 2.592 to 11.30 \\
\hline Garlic leaves & 13.53 & 34.67 & 21.14 & 16.79 to 25.49 \\
\hline p & Difference & $\mathbf{t}$ & $P$ value & Summary \\
\hline Garlic bulb & 6.945 & 5.501 & $\mathrm{P}<0.001$ & $* * *$ \\
\hline Garlic leaves & 21.14 & 16.75 & $\mathrm{P}<0.001$ & $* * *$ \\
\hline
\end{tabular}




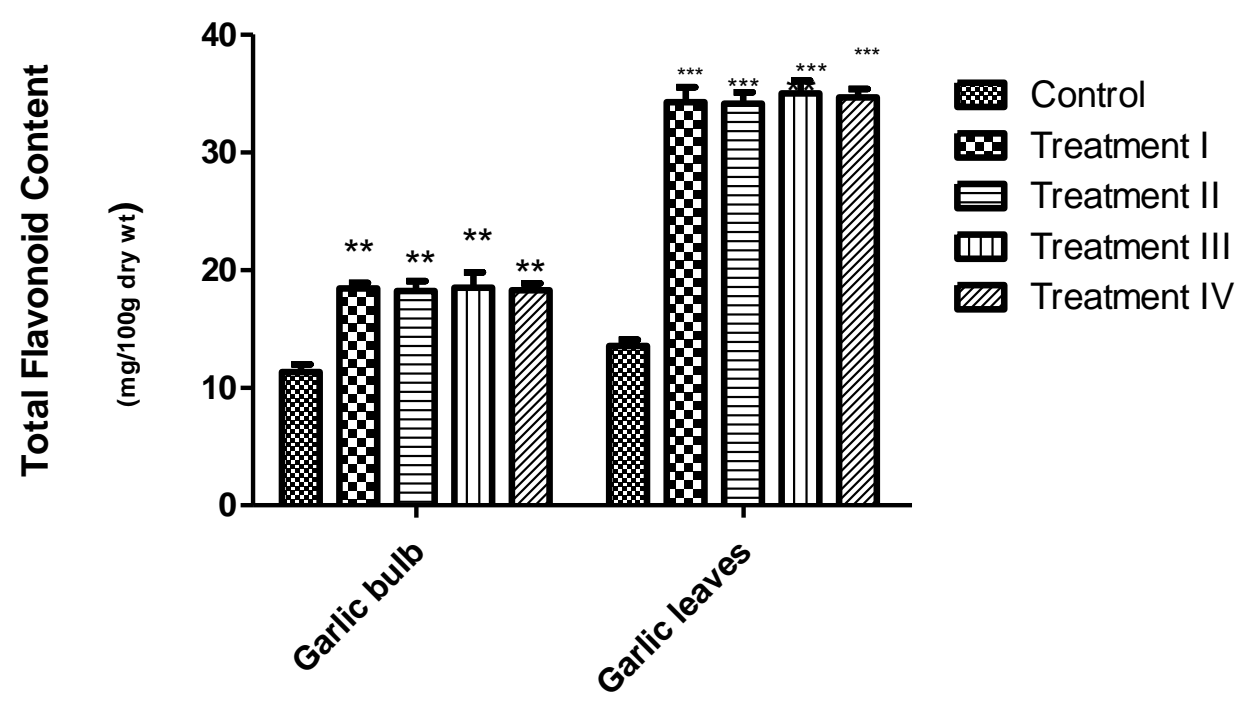

Figure 7. Total flavonoid content in garlic bulbs and leaves subjected to four various treatments. Error bars indicate standard error of the mean. (*) significantly different at $P<0.05$. (**) significantly different at $P<0.01$. (***) significantly different at $P<0.001$

\section{In vitro antioxidant activity}

The percentage DPPH radical scavenging capacity of garlic extracts with different treatments as well as controls is depicted in Figure 8. The $\mathrm{IC}_{50}$ values (sample concentration needed to scavenge 50\% of DPPH dye) of all garlic extracts as well as both standards (Vitamin C and BHT) were calculated by linear regression of plots. The lowest $\mathrm{IC}_{50}$ indicates the higher antiradical activity of extract. Garlic extract of treatment III had an IC IC $_{50}$ of $0.81 \mathrm{mg} / \mathrm{ml}$, followed by treatment IV $(0.82 \mathrm{mg} / \mathrm{ml})$, treatment I $(0.84$ $\mathrm{mg} / \mathrm{ml})$ and treatment II $(0.898 \mathrm{mg} / \mathrm{ml})$. The $\mathrm{IC}_{50}$ value of non treated (control) garlic extract was $0.97 \mathrm{mg} / \mathrm{ml}$. Of the two positive controls, BHT had the lowest $\mathrm{IC}_{50}(0.50$ $\mathrm{mg} / \mathrm{ml})$ than vitamin $\mathrm{C}(0.51 \mathrm{mg} / \mathrm{ml})$ but both showed significantly $(\mathrm{P}<0.05)$ higher DPPH scavenging activity than treated garlic extracts (Table 5).

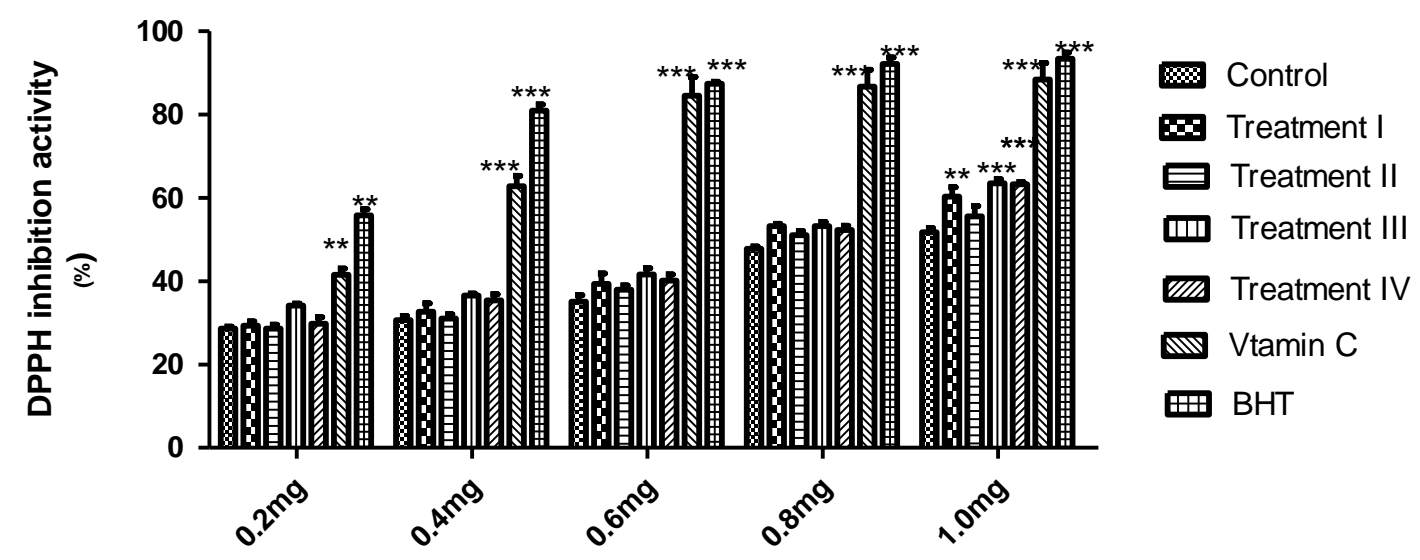

Figure 8. DPPH radical scavenging activity of treated Allium Sativum bulbous part extracts, synthetic antioxidant BHT and Vitamin $C$ in various concentrations. Error bars indicate standard error of the mean. $(*)$ significantly different at $P<0.05$. (**) significantly different at $P<0.01$. (***) significantly different at $P<0.001$ 
Table 5. ANOVA for antioxidant activity of garlic

\begin{tabular}{|c|c|c|c|c|}
\hline Source of Variation & \multicolumn{2}{|c|}{$\%$ of total variation } & \multicolumn{2}{|c|}{ P value } \\
\hline Interaction & \multicolumn{2}{|c|}{5.22} & \multicolumn{2}{|c|}{$<0.0001$} \\
\hline $\mathrm{t}$ & \multicolumn{2}{|c|}{60.99} & \multicolumn{2}{|c|}{$<0.0001$} \\
\hline $\mathrm{p}$ & \multicolumn{2}{|c|}{33.02} & \multicolumn{2}{|c|}{$<0.0001$} \\
\hline Source of Variation & \multicolumn{2}{|c|}{ P value summary } & \multicolumn{2}{|c|}{ Significant? } \\
\hline Interaction & \multicolumn{2}{|c|}{$* * *$} & \multicolumn{2}{|c|}{ Yes } \\
\hline $\mathrm{t}$ & \multirow{2}{*}{\multicolumn{2}{|c|}{$\begin{array}{l}* * * \\
* * *\end{array}$}} & \multicolumn{2}{|c|}{ Yes } \\
\hline $\mathrm{p}$ & & & \multicolumn{2}{|c|}{ Yes } \\
\hline Source of Variation & Df & Sum-of-squares & Mean square & $\mathbf{F}$ \\
\hline Interaction & 24 & 1547 & 64.46 & 9.849 \\
\hline $\mathrm{t}$ & 6 & 18080 & 3013 & 460.3 \\
\hline $\mathrm{p}$ & 4 & 9786 & 2447 & 373.8 \\
\hline Residual & 35 & 229.1 & 6.545 & \\
\hline Number of missing values & 0 & & & \\
\hline & & ni posttests & & \\
\hline & Con & Treatment I & & \\
\hline p & Control & Treatment I & Difference & $95 \%$ CI of diff. \\
\hline $0.2 \mathrm{mg}$ & 28.59 & 29.32 & 0.7300 & -7.986 to 9.446 \\
\hline $0.4 \mathrm{mg}$ & 30.64 & 32.66 & 2.020 & -6.696 to 10.74 \\
\hline $0.6 \mathrm{mg}$ & 35.11 & 39.39 & 4.280 & -4.436 to 13.00 \\
\hline $0.8 \mathrm{mg}$ & 47.81 & 53.27 & 5.460 & -3.256 to 14.18 \\
\hline $1.0 \mathrm{mg}$ & 51.74 & 60.30 & 8.560 & -0.1557 to 17.28 \\
\hline $\mathbf{p}$ & Difference & $\mathbf{t}$ & P value & Summary \\
\hline $0.2 \mathrm{mg}$ & 0.7300 & 0.2853 & $P>0.05$ & $\mathrm{~ns}$ \\
\hline $0.4 \mathrm{mg}$ & 2.020 & 0.7896 & $\mathrm{P}>0.05$ & ns \\
\hline $0.6 \mathrm{mg}$ & 4.280 & 1.673 & $\mathrm{P}>0.05$ & ns \\
\hline $0.8 \mathrm{mg}$ & 5.460 & 2.134 & $P>0.05$ & ns \\
\hline $1.0 \mathrm{mg}$ & 8.560 & 3.346 & $\mathrm{P}<0.01$ & $* *$ \\
\hline & Cont & Treatment II & & \\
\hline $\mathbf{p}$ & Control & Treatment II & Difference & $95 \%$ CI of diff. \\
\hline $0.2 \mathrm{mg}$ & 28.59 & 28.59 & 0.0000 & -8.716 to 8.716 \\
\hline $0.4 \mathrm{mg}$ & 30.64 & 31.05 & 0.4100 & -8.306 to 9.126 \\
\hline $0.6 \mathrm{mg}$ & 35.11 & 37.99 & 2.880 & -5.836 to 11.60 \\
\hline $0.8 \mathrm{mg}$ & 47.81 & 51.07 & 3.260 & -5.456 to 11.98 \\
\hline $1.0 \mathrm{mg}$ & 51.74 & 55.58 & 3.840 & -4.876 to 12.56 \\
\hline $\mathbf{p}$ & Difference & $\mathbf{t}$ & $P$ value & Summary \\
\hline $0.2 \mathrm{mg}$ & 0.0000 & 0.0000 & $P>0.05$ & $\mathrm{~ns}$ \\
\hline $0.4 \mathrm{mg}$ & 0.4100 & 0.1603 & $\mathrm{P}>0.05$ & ns \\
\hline $0.6 \mathrm{mg}$ & 2.880 & 1.126 & $P>0.05$ & ns \\
\hline $0.8 \mathrm{mg}$ & 3.260 & 1.274 & $\mathrm{P}>0.05$ & ns \\
\hline $1.0 \mathrm{mg}$ & 3.840 & 1.501 & $P>0.05$ & ns \\
\hline & Cont & Treatment III & & \\
\hline p & Control & Treatment III & Difference & $95 \%$ CI of diff. \\
\hline $0.2 \mathrm{mg}$ & 28.59 & 34.14 & 5.550 & -3.166 to 14.27 \\
\hline $0.4 \mathrm{mg}$ & 30.64 & 36.57 & 5.930 & -2.786 to 14.65 \\
\hline $0.6 \mathrm{mg}$ & 35.11 & 41.63 & 6.520 & -2.196 to 15.24 \\
\hline $0.8 \mathrm{mg}$ & 47.81 & 53.22 & 5.410 & -3.306 to 14.13 \\
\hline $1.0 \mathrm{mg}$ & 51.74 & 63.55 & 11.81 & 3.094 to 20.53 \\
\hline p & Difference & $\mathbf{t}$ & P value & Summary \\
\hline $0.2 \mathrm{mg}$ & 5.550 & 2.169 & $\mathrm{P}>0.05$ & ns \\
\hline $0.4 \mathrm{mg}$ & 5.930 & 2.318 & $\mathrm{P}>0.05$ & ns \\
\hline $0.6 \mathrm{mg}$ & 6.520 & 2.549 & $P>0.05$ & ns \\
\hline $0.8 \mathrm{mg}$ & 5.410 & 2.115 & $P>0.05$ & ns \\
\hline $1.0 \mathrm{mg}$ & 11.81 & 4.616 & $\mathrm{P}<0.001$ & $* * *$ \\
\hline & Cont & Treatment IV & & \\
\hline $\mathbf{p}$ & Control & Treatment IV & Difference & $95 \%$ CI of diff. \\
\hline $0.2 \mathrm{mg}$ & 28.59 & 29.82 & 1.230 & -7.486 to 9.946 \\
\hline $0.4 \mathrm{mg}$ & 30.64 & 35.41 & 4.770 & -3.946 to 13.49 \\
\hline $0.6 \mathrm{mg}$ & 35.11 & 40.16 & 5.050 & -3.666 to 13.77 \\
\hline $0.8 \mathrm{mg}$ & 47.81 & 52.32 & 4.510 & -4.206 to 13.23 \\
\hline $1.0 \mathrm{mg}$ & 51.74 & 63.31 & 11.57 & 2.854 to 20.29 \\
\hline
\end{tabular}




\begin{tabular}{|c|c|c|c|c|}
\hline $\mathbf{p}$ & Difference & $\mathbf{t}$ & P value & Summary \\
\hline $0.2 \mathrm{mg}$ & 1.230 & 0.4808 & $\mathrm{P}>0.05$ & $\mathrm{~ns}$ \\
\hline $0.4 \mathrm{mg}$ & 4.770 & 1.864 & $\mathrm{P}>0.05$ & ns \\
\hline $0.6 \mathrm{mg}$ & 5.050 & 1.974 & $P>0.05$ & ns \\
\hline $0.8 \mathrm{mg}$ & 4.510 & 1.763 & $\mathrm{P}>0.05$ & ns \\
\hline $1.0 \mathrm{mg}$ & 11.57 & 4.522 & $\mathrm{P}<0.001$ & $* * *$ \\
\hline \multicolumn{5}{|c|}{ Control vs Vtamin $\mathbf{C}$} \\
\hline $\mathbf{p}$ & Control & Vtamin C & Difference & $95 \%$ CI of diff. \\
\hline $0.2 \mathrm{mg}$ & 28.59 & 41.52 & 12.93 & 4.214 to 21.65 \\
\hline $0.4 \mathrm{mg}$ & 30.64 & 62.84 & 32.20 & 23.48 to 40.92 \\
\hline $0.6 \mathrm{mg}$ & 35.11 & 84.55 & 49.44 & 40.72 to 58.16 \\
\hline $0.8 \mathrm{mg}$ & 47.81 & 86.76 & 38.95 & 30.23 to 47.67 \\
\hline $1.0 \mathrm{mg}$ & 51.74 & 88.43 & 36.69 & 27.97 to 45.41 \\
\hline $\mathbf{p}$ & Difference & $\mathbf{t}$ & P value & Summary \\
\hline $0.2 \mathrm{mg}$ & 12.93 & 5.054 & $\mathrm{P}<0.001$ & $* * *$ \\
\hline $0.4 \mathrm{mg}$ & 32.20 & 12.59 & $\mathrm{P}<0.001$ & $* * *$ \\
\hline $0.6 \mathrm{mg}$ & 49.44 & 19.32 & $\mathrm{P}<0.001$ & $* * *$ \\
\hline $0.8 \mathrm{mg}$ & 38.95 & 15.22 & $\mathrm{P}<0.001$ & $* * *$ \\
\hline $1.0 \mathrm{mg}$ & 36.69 & 14.34 & $\mathrm{P}<0.001$ & $* * *$ \\
\hline \multicolumn{5}{|c|}{ Control vs BHT } \\
\hline $\mathbf{p}$ & Control & BHT & Difference & $95 \%$ CI of diff. \\
\hline $0.2 \mathrm{mg}$ & 28.59 & 55.80 & 27.21 & 18.49 to 35.93 \\
\hline $0.4 \mathrm{mg}$ & 30.64 & 80.92 & 50.28 & 41.56 to 59.00 \\
\hline $0.6 \mathrm{mg}$ & 35.11 & 87.40 & 52.29 & 43.57 to 61.01 \\
\hline $0.8 \mathrm{mg}$ & 47.81 & 92.20 & 44.39 & 35.67 to 53.11 \\
\hline $1.0 \mathrm{mg}$ & 51.74 & 93.40 & 41.66 & 32.94 to 50.38 \\
\hline $\mathbf{p}$ & Difference & $\mathbf{t}$ & P value & Summary \\
\hline $0.2 \mathrm{mg}$ & 27.21 & 10.64 & $\mathrm{P}<0.001$ & $* * *$ \\
\hline $0.4 \mathrm{mg}$ & 50.28 & 19.65 & $\mathrm{P}<0.001$ & $* * *$ \\
\hline $0.6 \mathrm{mg}$ & 52.29 & 20.44 & $\mathrm{P}<0.001$ & $* * *$ \\
\hline $0.8 \mathrm{mg}$ & 44.39 & 17.35 & $\mathrm{P}<0.001$ & $* * *$ \\
\hline $1.0 \mathrm{mg}$ & 41.66 & 16.28 & $\mathrm{P}<0.001$ & $* * *$ \\
\hline
\end{tabular}

\section{Discussion}

Micronutrients malnutrition is the insufficient availability of essential dietary microminerals to the population that will negatively impact the health of people and increase the risk of diseases (El-Ramady et al., 2015). Improvement of selected nutrients such as selenium in plants edible part through the process of biofortification will increase the nutritional value of food (Hirschi, 2008) which is proved through findings of current results that selenium concentration and polyphenolic content of selected garlic cultivar was enhanced through biofortification. Present results indicated that there is no considerable difference in fresh wt yield of treated and control sets of garlic plants. These results are in consistent with the findings of Põldma et al. (2013), who reported that effects of selenium treatment on yield of onion bulb (Allium cepa L.) was not significant and at $\operatorname{Se} 50(50 \mu \mathrm{g} / \mathrm{ml})$ there was no reduction in bulb size as compared to Se100 $(100 \mu \mathrm{g} / \mathrm{ml})$. However, these observations are contradictory to Yadav et al. (2007) who reported that leaves and bulbs of Allium cepa were reduced in size at high concentration of $50 \mu \mathrm{g} / \mathrm{g}$ Se spiked soil. High concentration of selenium (50g/ha) foliar application enhances the dry matter content of the whole plant. Current findings showed that on increasing the concentration of available selenium salt $\left(\mathrm{Na}_{2} \mathrm{SeO}_{4}\right)$, accumulation of selenium content was increased in garlic plants. Foliar application of $20 \mathrm{mgSem}^{-2}$ and $50 \mathrm{mgSem}^{-2}$ to garlic plants resulted in 7.8 and 12.52 fold increase of selenium content in garlic bulbs as compared to control. Similarly, 3.52 fold increase of selenium content was observed in vegetative part of garlic plants on $50 \mathrm{mgSem}^{-2}$ foliar spray (Figure 5), which could be used as fodder for animals to 
improve their nutritional value regarding selenium content.Hegedüsová et al. (2017) reported that foliar application of selenium salt to Ambassdor pea variety at two concentrations i.e. $5 \mathrm{mgSe} / \mathrm{m}^{2}$ and $10 \mathrm{mgSe} / \mathrm{m}^{2}$ resulted in 25.4 and 49.1 fold enhancement of selenium content, depending on applied doses. Similar observations were reported by Yadav et al. (2007) that selenium accumulation in tissues of Allium cepa was improved from 278 to $1248.8 \mu \mathrm{g} / \mathrm{g}$ along with increasing Se concentration from $25 \mu \mathrm{g} / \mathrm{g}$ to $50 \mu \mathrm{g} / \mathrm{g}$ of soil, respectively. Whanger et al. (2000) was also reported that selenium uptake of Allium tricoccum was enhanced with increasing concentration of available Selenium, despite the nature of experimental media including peatmoss (I), vermiculite and hydroponics (III). Seleniferous plants has the potential to mobilize inorganic form of selenium from soil, and to accumulate it in the biomass in organic form making it more bioavailable to animals and human beings, which is proved by the study of Yan and Johnson (2011). Due to this inherited ability of the crop plants belonging to Allium family, they can be grown in those geographical areas that naturally enriched with selenium loaded soil, to do the work of phytoremediation. Hasanuzzaman et al. (2010) reported that selenium accumulators have the ability to accumulate $4000 \mathrm{mg} / \mathrm{kg}$ selenium without exhibiting signs of toxicity in comparison to non seleniferous plants like rice, which showed $10 \%$ yield reduction on selenium threshold level of $2 \mathrm{mg} / \mathrm{kg}$ in shoot tissues. Thus biofortification can be indirectly linked with phytoremediation (Yadav et al., 2007). These selenium biofortified garlic can be exported as food commodity in those specific areas of the world such as China (Tan et al., 2002) that naturally deficient for selenium. Daily intake portion $(80 \mathrm{~g})$ of selenium biofortified rice for 20days can significantly increase the serum selenium level, which is confirmed by Giacosa et al. (2014). Based on the results shown in Figure 5, it can be assumed that daily intake of $16 \mathrm{~g}$ of dried garlic bulb procured in treatment III can cover the daily recommended dose (40ug to 50ug for adults) of selenium (Burk et al., 2003).

Food enriched with polyphenolic compounds such as phenolics, flavonols and flavonoids have been reported to exhibit strong antioxidant activities which protects the cells from damaging effects of free radicals and reduces the risk of chronic diseases (Otunola and Afolayan, 2013).In this study, selenium accumulation in garlic biomass enhances the nutritional value and antioxidant capacity of garlic plant. Significant value of phenolic content that is $4.72 \mathrm{mgGAE} / 100 \mathrm{~g}$ dry wt of garlic was observed in the present study. Beato et al. (2011) had reported that the total phenolic content in four garlic cultivars varied from $3.4 \mathrm{mg}$ GAE/100 g dry wt to $10.8 \mathrm{mg}$ GAE/100 g dry wt with a mean value of $6.5 \mathrm{mg}$ GAE/100 g dry wt grown at Andalusia, Spain. They reported ferulic acid and caffeic acid were the major polyphenols present in garlic with mean values of 2.6 and $2.9 \mathrm{mg} / \mathrm{kg}$ of dry matter, respectively. In the present study, considerable amount of total flavonoid content (TFC) were observed in garlic extracts of all treatments depending on the amount of available selenium in comparison to control plant. Higher value of TFC of garlic extract $(18.50 \pm 1.82 \mathrm{mgQE} / 100 \mathrm{~g}$ dry wt) in treatment III could be related to increased concentration of available selenium salt $(50 \mathrm{~g} / \mathrm{ha})$. Stable DPPH free radical scavenging assay is a commonly used method for the estimation of free radical scavenging ability of various compounds (Ghasemi et al., 2015). In the current study, results showed that there was a significant $(P<0.05)$ increase in the scavenging ability of DPPH-radical as dose of garlic extract increased (Figure 8). This trend is similar to results of Park et al. (2009) who accounted that garlic extracts exhibited remarkable scavenging properties by reducing stable radical DPPH to yellow colored diphenyl picrylhydrazine. This could be due to the hydrogen donating 
ability of various vegetable extracts from their phenolic hydroxyl groups. Previously, Velioglu et al. (1998) reported a considerable association between phenolic content and antioxidant activity of various fruits, cereals and vegetable extracts. Kavalcová et al. (2014) reported statistically considerable value of antioxidant activity (4.05\% to $5.07 \%)$ in association with polyphenolic content $(260$ t0 $279 \mathrm{mg} / \mathrm{Kg}$ ) in garlic samples collected from Pruzina, Strazov. Similarly, experimental garlic bulb obtained in treatment III exhibited a significant relation between higher value of polyphenolic content (2.59 to $4.72 \mathrm{mg} / 100 \mathrm{~g})$ and total antioxidant capacity $(93.75 \pm 1.54 \%)$.

\section{Conclusion}

The present study revealed that garlic selenium content was increased through biofortification process in field conditions. The process of selenium fertilization through foliar spray was more effective than soil irrigation and positive for all biochemical parameters analyzed. High polyphenolic content and antioxidant properties were observed in biofortified garlic in concordant with high selenium content which could be used as a powerful source of natural antioxidants along with selenium to combat hidden hunger of micronutrient. Further field experiments conducted in the present study will shade a new light to improve selenium content in other seleniferous crops which could be valuable considering agronomic and human health benefits.

Acknowledgements. The authors are grateful to the management of PCSIR labs complex Lahore for financial assistance.

Conflict of interests. Authors declare no conflict of interests.

Geographic information. Field experiments were conducted at botanical garden of PCSIR Labs Complex, Lahore, Pakistan. The experimental site is situated between $31.52^{\circ}$ North latitude, $74.33^{\circ}$ East longitude and altitude of $217 \mathrm{~m}$ above the sea level.

\section{REFERENCES}

[1] Adhikari, P. (2012): Biofortification of Selenium in broccoli (Brassica oleracea L. var. italica) and onion (Allium cepa L.). - Norwegian University of Life Sciences, Ås.

[2] AOAC (1990): Official methods of Analysis. 5th ed. - Association of Official Analytical Chemists, Arlington, VA.

[3] Beato, V. M., Orgaz, F., Mansilla, F., Montaño, A. (2011): Changes in phenolic compounds in garlic (Allium sativum L.) owing to the cultivar and location of growth. Plant Foods for Human Nutrition (Formerly Qualitas Plantarum) 66: 218-223.

[4] Beck, M. A., Levander, O. A., Handy, J. (2003) Selenium deficiency and viral infection. - The Journal of nutrition 133: 1463S-1467S.

[5] Birringer, M., Pilawa, S., Flohé, L. (2002): Trends in selenium biochemistry. - Natural product reports 19: 693-718.

[6] Bouis, H. E., Hotz, C., Mcclafferty, B., Meenakshi, J., Pfeiffer, W. H. (2011): Biofortification: a new tool to reduce micronutrient malnutrition. - Food and nutrition bulletin 32: S31-S40.

[7] Bouis, H. E., Welch, R. M. (2010): Biofortification - a sustainable agricultural strategy for reducing micronutrient malnutrition in the global south. - Crop Science 50: S20-S32.

[8] Brand-Williams, W., Cuvelier, M.-E., Berset, C. (1995): Use of a free radical method to evaluate antioxidant activity. - LWT-Food science and Technology 28: 25-30. 
[9] Burk, R. F. (2002): Selenium, an antioxidant nutrient. - Nutrition in clinical Care 5: 7579.

[10] Burk, R. F., Hill, K. E., Motley, A. K. (2003): Selenoprotein metabolism and function: evidence for more than one function for selenoprotein P. - The Journal of nutrition 133: 1517S-1520S.

[11] Burk, R. F., Hill, K. E., Motley, A. K., Byrne, D. W., Norsworthy, B. K. (2015): Selenium deficiency occurs in some patients with moderate-to-severe cirrhosis and can be corrected by administration of selenate but not selenomethionine: a randomized controlled trial-3. - The American journal of clinical nutrition 102: 1126-1133.

[12] Carvalho, S. M., Vasconcelos, M. W. (2013): Producing more with less: strategies and novel technologies for plant-based food biofortification. - Food res. intl. 54: 961-971.

[13] Chang, C.-C., Yang, M.-H., Wen, H.-M., Chern, J.-C. (2002) Estimation of total flavonoid content in propolis by two complementary colorimetric methods. - Journal of food and drug analysis 10.

[14] Chen, S., Shen, X., Cheng, S., Li, P., Du, J., Chang, Y., Meng, H. (2013): Evaluation of garlic cultivars for polyphenolic content and antioxidant properties. - PLoS One 8: e79730.

[15] Choi, I. S., Cha, H. S., Lee, Y. S. (2014): Physicochemical and antioxidant properties of black garlic. - Molecules 19: 16811-16823.

[16] Clark, L. C., Combs, G. F., Turnbull, B. W., Slate, E. H., Chalker, D. K., Chow, J., Davis, L. S., Glover, R. A., Graham, G. F., Gross, E. G. (1996): Effects of selenium supplementation for cancer prevention in patients with carcinoma of the skin: a randomized controlled trial. - Jama 276: 1957-1963.

[17] El-Ramady, H., Abdalla, N., Alshaal, T., Domokos-Szabolcsy, E., Elhawat, N., Prokisch, J., Sztrik, A., Fári, M., El-Marsafawy, S., Shams, M. S. (2015): Selenium in soils under climate change, implication for human health. - Environmental chemistry letters 13(1).

[18] Fordyce, F. M. (2013): Selenium deficiency and toxicity in the environment. - Essentials of medical geology. Springer.

[19] Ghasemi, K., Bolandnazar, S., Tabatabaei, S., Pirdashti, H., Arzanlou, M., Ebrahimzadeh, M., Fathi, H. (2015): Antioxidant properties of garlic as affected by selenium and humic acid treatments. - New Zealand Journal of Crop and Horticultural Science 43: 173-181.

[20] Giacosa, A., Faliva, M. A., Perna, S., Minoia, C., Ronchi, A., Rondanelli, M. (2014): Selenium fortification of an Italian rice cultivar via foliar fertilization with sodium selenate and its effects on human serum selenium levels and on erythrocyte glutathione peroxidase activity. - Nutrients 6: 1251-1261.

[21] González-Morales, S., Pérez-Labrada, F., García-Enciso, E. L., Leija-Martínez, P., Medrano-Macías, J., Dávila-Rangel, I. E., Juárez-Maldonado, A., Rivas-Martínez, E. N., Benavides-Mendoza, A. (2017): Selenium and Sulfur to Produce Allium Functional Crops. - Molecules 22: 558.

[22] GraphPad Software, Version 5.0 (2009). San Diego, California, USA (www. graphpad. com).

[23] Guide, E. (1998): The fitness for purpose of analytical methods: a laboratory guide to method validation and related topics. - LGC (Teddington) Ltd. ISBN 0-948926-12-0.

[24] Hartikainen, H. (2005): Biogeochemistry of selenium and its impact on food chain quality and human health. - Journal of Trace Elements in Medicine and Biology 18: 309-318.

[25] Hasanuzzaman, M., Hossain, M. A., Fujita, M. (2010): Selenium in higher plants: physiological role, antioxidant metabolism and abiotic stress tolerance. - J Plant Sci 5: 354-375.

[26] Hegedűsová, A., Mezeyová, I., Hegedűs, O., Andrejiová, A., Juríková, T., Golian, M., Lošák, T. (2017) Increasing of selenium content and qualitative parameters in garden pea (Pisum sativum L.) after its foliar application. - Acta Scientiarum Polonorum-Hortorum Cultus 16: 3-17. 
[27] Hirschi, K. (2008): Nutritional improvements in plants: time to bite on biofortified foods. - Trends in plant science 13: 459-463.

[28] Holben, D. H., Smith, A. M. (1999) The diverse role of selenium within selenoproteins: a review. - Journal of the Academy of Nutrition and Dietetics 99: 836-843.

[29] Kardinaal, A. F., Kok, F. J., Kohlmeier, L., Martin-Moreno, J. M., Ringstad, J., GómezAracena, J., Mazaev, V. P., Thamm, M., Martin, B. C., Aro, A. (1997): Association between toenail selenium and risk of acute myocardial infarction in European men: the EURAMIC Study. - American journal of epidemiology 145: 373-379.

[30] Kaur, C. \& Kapoor, H. C. (2002): Anti-oxidant activity and total phenolic content of some Asian vegetables. - International Journal of Food Science \& Technology 37: 153161.

[31] Kavalcová, P., Bystrická, J., Tomáš, J., Karovičová, J., Kuchtová, V. (2014): Evaluation and comparison of the content of total polyphenols and antioxidant activity in onion, garlic and leek. - Potravinarstvo Slovak Journal of Food Sciences 8: 272-276.

[32] Li, Z., Liang, D., Peng, Q., Cui, Z., Huang, J., Lin, Z. (2017): Interaction between selenium and soil organic matter and its impact on soil selenium bioavailability: A review. - Geoderma 295: 69-79.

[33] Lobanov, A. V., Hatfield, D. L., Gladyshev, V. N. (2008): Reduced reliance on the trace element selenium during evolution of mammals. - Genome biology 9: R62.

[34] Meier, U., Bleiholder, H., Buhr, L., Feller, C., Hack, H., Heß, M., Lancashire, P. D., Schnock, U., Stauß, R., Van Den Boom, T. (2009): The BBCH system to coding the phenological growth stages of plants-history and publications. - Journal für Kulturpflanzen 61: 41-52.

[35] Mikkelsen, R., Page, A., Bingham, F. (1989): Factors affecting selenium accumulation by agricultural crops. - Selenium in Agriculture and the Environment: 65-94.

[36] Morihara, N., Ide, N., Weiss, N. (2010): Aged garlic extract inhibits CD36 expression in human macrophages via modulation of the PPAR $\gamma$ pathway. - Phytotherapy research 24: 602-608.

[37] Muthayya, S., Rah, J. H., Sugimoto, J. D., Roos, F. F., Kraemer, K., Black, R. E. (2013): The global hidden hunger indices and maps: an advocacy tool for action. - PLoS One 8: e67860.

[38] Oropeza-Moe, M., Wisløff, H., Bernhoft, A. (2015): Selenium deficiency associated porcine and human cardiomyopathies. - Journal of Trace Elements in Medicine and Biology 31: 148-156.

[39] Otunola, G. A., Afolayan, A. J. (2013): Evaluation of the polyphenolic contents and antioxidant properties of aqueous extracts of garlic, ginger, cayenne pepper and their mixture. - Journal of Applied Botany and Food Quality 86.

[40] Park, J.-H., Park, Y. K., Park, E. (2009): Antioxidative and antigenotoxic effects of garlic (Allium sativum L.) prepared by different processing methods. - Plant Foods for Human Nutrition (Formerly Qualitas Plantarum) 64: 244-249.

[41] Peschel, W., Sánchez-Rabaneda, F., Diekmann, W., Plescher, A., Gartzía, I., Jiménez, D., Lamuela-Raventos, R., Buxaderas, S., Codina, C. (2006): An industrial approach in the search of natural antioxidants from vegetable and fruit wastes. - Food Chemistry 97: 137150.

[42] Pfeiffer, W. H., Mcclafferty, B. (2007): HarvestPlus: breeding crops for better nutrition. Crop Science 47: S88-S105.

[43] Põldma, P., Moor, U., Tõnutare, T., Herodes, K., Rebane, R. (2013): Selenium treatment under field conditions affects mineral nutrition, yield and antioxidant properties of bulb onion (Allium cepa L.). - Acta Sci Pol Hortoru 12(6):167-181.

[44] Rehse, S., Kloas, W., Zarfl, C. (2016): Short-term exposure with high concentrations of pristine microplastic particles leads to immobilisation of Daphnia magna. - Chemosphere 153:91-99. 
[45] Rouached, H. (2013): Recent developments in plant zinc homeostasis and the path toward improved biofortification and phytoremediation programs. - Plant signaling \& behavior 8: e22681.

[46] Singleton, V. L., Rossi, J. A. (1965): Colorimetry of total phenolics with phosphomolybdic-phosphotungstic acid reagents. - American journal of Enology and Viticulture 16: 144-158.

[47] Steinbrenner, H., Sies, H. (2009): Protection against reactive oxygen species by selenoproteins. - Biochimica et Biophysica Acta 1790: 1478-1485.

[48] Swaminathan, M. (2012) Combating hunger. - American Association for the Advancement of Science.

[49] Tan, J. A., Zhu, W., Wang, W., Li, R., Hou, S., Wang, D., Yang, L. (2002): Selenium in soil and endemic diseases in China. - Science of the Total Environment 284: 227-235.

[50] Terry, N., Zayed, A., De Souza, M., Tarun, A. (2000): Selenium in higher plants. Annual review of plant biology 51: 401-432.

[51] Velioglu, Y., Mazza, G., Gao, L., Oomah, B. (1998): Antioxidant activity and total phenolics in selected fruits, vegetables, and grain products. - Journal of agricultural and food chemistry 46: 4113-4117.

[52] Webb, H. K., Arnott, J., Crawford, R. J., Ivanova, E. P. (2012): Plastic degradation and its environmental implications with special reference to poly (ethylene terephthalate). Polymers 5:1-18.

[53] Whanger, P., Ip, C., Polan, C., Uden, P., Welbaum, G. (2000): Tumorigenesis, metabolism, speciation, bioavailability, and tissue deposition of selenium in seleniumenriched ramps (Allium tricoccum). - Journal of agricultural and food chemistry 48: 5723-5730.

[54] Yadav, S., Gupta, S., Prakash, P., Spallholz, J., Prakash, N. (2007): Selenium uptake by Allium cepa grown in Se-spiked soils. - American-Eurasian Journal of Agricultural \& Environmental Sciences 2: 80-84.

[55] Yan, L., Johnson, L. K. (2011): Selenium bioavailability from naturally produced highselenium peas and oats in selenium-deficient rats. - Journal of agricultural and food chemistry 59: 6305-6311.

[56] Yang, D.-Y., Chen, Y.-W., Gunn, J. M., Belzile, N. (2008): Selenium and mercury in organisms: interactions and mechanisms. - Environmental Reviews 16: 71-92.

[57] Zayed, A., Lytle, C. M., Terry, N. (1998): Accumulation and volatilization of different chemical species of selenium by plants. - Planta 206: 284-292.

[58] Zhao, F.-J., Mcgrath, S. P. (2009) Biofortification and phytoremediation. - Current opinion in plant biology 12: 373-380.

[59] Zuo, Y., Zhang, F. (2011) Soil and crop management strategies to prevent iron deficiency in crops. - Plant and Soil 339: 83-95. 